\title{
Developmental Changes in Endothelial Vasoactive and Angiogenic Growth Factors in the Human Perinatal Lung
}

\author{
MARILYNE LEVY, CHRISTELLE MAUREY, BERNADETTE CHAILLEY-HEU, \\ JELENA MARTINOVIC, FRANCIS JAUBERT, AND DOMINIQUE ISRAËL-BIET

\begin{abstract}
Laboratoire d'Immunopathologie Pulmonaire UPRES EA220 [M.L., C.M., D.I.-B.], UFR Biomedicale des Saints Pères, 75006 Paris, France, Services de Chirurgie Cardiaque [M.L.], Services de Cytogenetique [J.M.], Services d'Anatomo-Pathologie [F.J.], Hôpital Necker-Enfants Malades, Assistance Publique-Hôpitaux de Paris, 75015 Paris, France, INSERM U492 [B.C.-H.], 94000 Creteil, France
\end{abstract}

\begin{abstract}
LBST
Little is known of the mechanisms underlying the marked fall
in pulmonary vascular resistance that occurs at birth, but changes
in the expression of endothelial vasoactive and angiogenic fac-
tors during lung development might play a key role. Nitric oxide,
endothelin-1, and vascular endothelial growth factor have critical
effects on vascular tone and cell growth. Here, we investigated
the protein expression of endothelial nitric oxide synthase, en-
dothelin-1 and its receptors, and vascular endothelial growth
factor in pulmonary necropsy samples from 14 fetuses of differ-
ent gestational ages and from 5 infants. Expression of endothe-
lin-1 and its receptor endothelin-A was strong and stable. In
contrast, expression of the endothelin-B receptor was weak in
early gestation, then increased markedly in mid-gestation and
remained high thereafter. The expression of endothelial nitric
oxide synthase and vascular endothelial growth factor fell mark-
\end{abstract}
During gestation, the placenta ensures the totality of maternofetal gas exchange. Fetal lung development is associated with high PVR, with $<10 \%$ of ventricular output entering the lungs. The mechanisms underlying these high PVR in fetal lung are not entirely clear and might involve lack of ventilation, low oxygen pressure, and, possibly, regulated expression of endothelial vasoactive and angiogenic factors with a preponderance of vasoconstrictive ones (1-3). The perinatal transition of gas exchanges from the placenta to the lungs at birth requires a marked and sharp decrease in PVR, allowing the pulmonary blood flow to increase 8- to 10-fold during the first hours of life. The mechanisms underlying this phenomenon

Received August 11, 2003; accepted July 19, 2004

Correspondence: Marilyne Levy, M.D., Ph.D., Service de Chirurgie Cardiaque, Hôpital Necker-Enfants Malades, 149 rue de Sèvres, 75015 Paris, France; e-mail: marilyne.levy@nck.ap-hop-paris.fr

Supported by SESERAC (Société d'Etudes et de Soins pour les Enfants atteints de Rhumatisme articulaire aigu et de Cardiopathies) and Société Française de Cardiologie (Bourse Hélène de Marsan).

DOI: 10.1203/01.PDR.0000148280.86670.7B edly after mid-gestation and remained low thereafter. These data point to a discrepancy between maturational and functional changes in human pulmonary vascular structures. The weak perinatal expression of endothelial nitric oxide could suggest that other potent vasodilatory mediators are responsible for the marked vasodilation observed at birth. (Pediatr Res 57: 248253, 2005)

$\quad$ Abbreviations
EDHF, endothelial-derived hyperpolarizing factor
ET, endothelin
NO, nitric oxide
NOS, nitric oxide synthase
PVR, pulmonary vascular resistance
VEGF, vascular endothelial growth factor

have not been elucidated and appear to involve rhythmic distension of the lung, increased oxygenation, shear stress, and changes in vasoactive factor expression (3). In experimental animals, the basal pulmonary vessel tone appears to be tightly regulated by a balance between endothelium-derived mediators, some of which display major vasodilating effects, such as NO, EDHF, and prostacyclin, and some potent vasoconstrictive effects, such as and ET-1 and leukotrienes (4-10). NO, for instance, produced from L-arginine by the action of a constitutive eNOS, is clearly involved in the postnatal fall in PVR in rats, lambs, and piglets $(1,11,12)$. The effects of ET-1, mediated through two different sets of receptors, ET-A and ET-B, are more ambiguous (13). ET-A, mostly present on vascular smooth muscle cells, mediates vasoconstriction. ET-B, on the other hand, might participate both in the release of vasodilatory mediators such as $\mathrm{NO}$ when located on endothelial cells and in vasoconstriction through its location on vascular smooth muscle cells $(10,14-17)$. In rats and lambs, the gradual rise in pulmonary eNOS expression with advancing gestational age matches the perinatal transition from the saccular to the alve- 
olar stage of lung development $(1,12)$. In humans, in contrast, alveolarization starts several weeks before birth. Both endothelial vasoactive and angiogenic factors are critical during this transitional period, and an altered pulmonary vasculature structure and/or function can hinder postnatal pulmonary adaptation (18-20). Among the most potent angiogenic factors, VEGF is a specific endothelial cell mitogen that regulates endothelial cell differentiation and angiogenesis (21-23). It is thought to play a key role in the vascular development of the human fetal lung (24). Its expression throughout this development relatively to that of the vasoactive factors is largely unknown. Likewise, the expression of eNOS relative to that of the ET-1 balance, thought to be critical in the marked vasodilation that occurs in the human lung at birth, is presently unclear.

In order to find clues to the role of the various factors in the sharp adaptation of PVR that occurs at birth, we evaluated eNOS, ET-1, and VEGF expression in the pulmonary arteries throughout gestation and at birth in 14 human fetuses of different gestational ages and in five infants.

\section{MATERIALS AND METHODS}

Study population. Fourteen fetuses aborted for major nonpulmonary abnormalities were included in this study, which was approved by the local ethics committee (Table 1). None of these fetuses had known lung abnormalities, and the two fetuses with bone abnormalities had no thoracic deformation. The fetuses were separated into three groups according to the classical lung development stages (20), i.e. canalicular (16-24 wk gestation, $n=5)$, saccular (25-35 wk, $n=5$ ), and alveolar (36-41 wk, $n=4)$, and were compared with five infants who died of nonpulmonary causes. One of the five infants died just after delivery at $41 \mathrm{wk}$ after having breathed naturally. Four infants died of sudden infant death syndrome between 3 and 6 mo of age. In fetuses as well as in infants, autopsies were performed within $24 \mathrm{~h}$ of death or abortion. Lung tissues were fixed in $10 \%$ neutral buffered formalin for $48 \mathrm{~h}$ before being processed. Lung tissues were also flash frozen in liquid nitrogen and stored at $-80^{\circ} \mathrm{C}$. The lungs were macroscopically and microscopically normal in all the fetuses and infants. The lung structure of the infants of $1 \mathrm{~d}, 3 \mathrm{mo}$, and $6 \mathrm{mo}$ were comparable with respect to lung expansion and thin-walled pulmonary arteries.

Table 1. Clinical data

\begin{tabular}{ccl}
\hline & Age at death & \multicolumn{1}{c}{ Diagnosis of death } \\
\hline Fetus & & \\
1 & $16 \mathrm{wk}$ & Anencephaly \\
2 & $19 \mathrm{wk}$ & Spina Bifida \\
3 & $20 \mathrm{wk}$ & Drepanocytose \\
4 & $23 \mathrm{wk}$ & Apert syndrome \\
5 & $24 \mathrm{wk}$ & Bone anomalies \\
6 & $26 \mathrm{wk}$ & Microcephaly \\
7 & $27 \mathrm{wk}$ & Bone anomalies \\
8 & $31 \mathrm{wk}$ & Cerebral anomalies \\
9 & $33 \mathrm{wk}$ & Microcephaly \\
10 & $34 \mathrm{wk}$ & Achondrodysplasy \\
11 & $36 \mathrm{wk}$ & Cerebral anomalies \\
12 & $36 \mathrm{wk}$ & Cerebral anomalies \\
13 & $38 \mathrm{wk}$ & Cerebral anomalies \\
14 & $41 \mathrm{wk}$ & Hydrocephaly \\
Infant & & \\
1 & $1 \mathrm{~d}$ & Forceps \\
2 & $3 \mathrm{mo}$ & Sudden infant death syndrome \\
3 & $3 \mathrm{mo}$ & Sudden infant death syndrome \\
4 & $6 \mathrm{mo}$ & Sudden infant death syndrome \\
5 & $6 \mathrm{mo}$ & Sudden infant death syndrome \\
\hline
\end{tabular}

Immunohistochemistry. Lung necropsy samples were fixed in $10 \%$ neutral buffered formalin for $48 \mathrm{~h}$, embedded in paraffin, and kept in dry storage at room temperature. Four-micrometer sections were stained with hematoxylineosin and Miller's elastin-van Gieson stains for morphologic studies. In addition, adjacent sections were studied immunohistochemically. Briefly, sections were deparaffinized in toluene, rehydrated through graded concentrations of ethanol, and heated for $40 \mathrm{~min}$ in citrate buffer $\mathrm{pH} 6$ in a $97^{\circ} \mathrm{C}$ water bath. The slides were incubated with hydrogen peroxide to block endogenous peroxidase activity and washed in Tris-buffered saline. They were then incubated for $1 \mathrm{~h}$ at room temperature with the following primary antibodies: mouse MAb to human eNOS (1:100 final dilution (BD Transduction Laboratories, Lexington, KY), ET-1 (1:200, Affinity Bioreagents, Golden, CO) and ET-A and ET-B receptors (1:100 and 1:150, respectively, Alexis Biochemicals, San Diego, CA), or a rabbit polyclonal antibody to VEGF (1:100, A-20; Santa Cruz Biotechnology, Santa Cruz, CA). Irrelevant antibodies of the same species and isotype (polyclonal rabbit anti-human thyroglobulin, DAKO, Carpenteria, CA) served as controls. Negative controls omitted the primary antibody. The sections were then incubated with a biotinylated anti-mouse or anti-rabbit secondary antibody for $15 \mathrm{~min}$ at room temperature. Labeling was revealed by incubation with a streptavidin-horseradish peroxidase complex, according to the manufacturer's instructions (DAKO). Slides were counterstained with Harris' hematoxylin and mounted in aqueous medium.

Three investigators blinded to the age of the fetuses or infants examined all the slides independently, using a four-point semiquantitative scoring system to grade the intensity of each immunolabel in pulmonary arteries (0: no staining, 1: weak, 2: moderate, 3: intense staining). All experimental and control slides used to study a given mediator were prepared in parallel to avoid technical variability. The results were expressed as the mean $\pm \mathrm{SD}$ of their scores. Interobserver variability was always $<5 \%$. Each immunolabel was similar in intensity in proximal and distal pulmonary arteries $(<200 \mu \mathrm{m})$. We therefore focused on the latter, which are involved in vascular reactivity.

Western blot analysis. Lung tissues were homogenized in Tris- $\mathrm{HCl}$ containing protease inhibitors $(0.1 \mathrm{mM})$, and the homogenates were centrifuged at $10,000 \mathrm{~g}$ for $10 \mathrm{~min}$. Supernatant fractions were collected for total protein assay (Bradford assay kit, Bio-Rad, Hercules, CA) and Western blot analysis. Fifty micrograms of protein was separated by electrophoresis on an $8 \%$ polyacrylamide gel using Tris-glycine-SDS buffer. The separated proteins were transferred to nitrocellulose membranes at $1.2 \mathrm{~mA} / \mathrm{cm}^{2}$ for $1 \mathrm{~h}$ and $45 \mathrm{~min}$ in transfer buffer (25 mM Tris-HCl, $192 \mathrm{mM}$ glycine, $20 \%$ methanol). The membranes were blocked with $5 \%$ nonfat dried milk in Tris-buffered saline [(TBS) $10 \mathrm{mM}$ Tris $\mathrm{pH} 7.4,100 \mathrm{mM} \mathrm{NaCl}$ ] and then incubated overnight at $4^{\circ} \mathrm{C}$ with either a mouse monoclonal anti-eNOS antibody (1:500) (BD Transduction Laboratories) or a rabbit polyclonal anti-human VEGF antibody (1:1000) (Santa Cruz Biotechnology). The membranes were then rinsed three times for $10 \mathrm{~min}$ each in TBS- $0.1 \%$ Tween and incubated for $1 \mathrm{~h}$ at room temperature with anti-mouse $\operatorname{IgG}$ (1:500) or an anti-rabbit IgG-horseradish peroxidase conjugate (1:500), for eNOS and VEGF, respectively. After three 10-min rinses, the reaction was developed using the Western Lightning Chemiluminescence Reagent Plus (PerkinElmer Life Science, Boston, MA) on Kodak BioMax Light-1 films (Eastman Kodak, Rochester, NY). Band densitometry was performed using National Institutes of Health image analysis software. Results for eNOS were standardized using a lysate of a human aortic endothelial cell line (BD Transduction Laboratories), which also served as a positive control. Experimental eNOS and VEGF data are expressed as a percentage of the values obtained in infants. In these experiments, we could not use actin as a housekeeping protein because its expression also varied during lung development.

ELISA to detect active ET-1. The Biotrak ET-1 ELISA system (Amersham Pharmacia Biotech UK, Ltd., Little Chalfont, Buckinghamshire, UK) was used to detect ET-1 production by the lungs of fetuses and infants. Supernatant fractions from homogenized lung tissues were processed. ET-1 in the samples tested was captured by microtiter plates precoated with ET-1 antibody and detected by a peroxidase-labeled Fab' fragment of ET-1 antibody conjugate.

Statistical analysis. Results are expressed as means \pm SD. ANOVA was applied to all data. When ANOVA was significant, comparisons between two groups were made using Mann-Whitney $U$ test. A $p$ value $<0.05$ was considered significant. 


\section{RESULTS}

Lungs obtained at 16-24 wk of gestation exhibited an immature parenchyma with immature vascular and bronchial structures. Increasing gestational age was associated with increased alveolarization, thinning of vessel walls, and increasing numbers of distal arteries and capillaries.

ET-1 and its receptors. ET-1 immunolabeling was detected on vascular endothelium and vascular smooth muscle cells of all samples. Its intensity was similar at the two arterial sites and the corresponding scores were therefore pooled. ET-1 expression did not vary significantly during gestation $(1.8 \pm 0.27$, $2.41 \pm 0.58$, and $1.83 \pm 0.28$ at the canalicular, saccular, and alveolar stages, respectively). As a whole, it was higher throughout gestation than after birth $(1.16 \pm 0.56 ; p<0.01$ compared with the saccular stage and $p<0.05$ compared with the canalicular and alveolar stages) (Fig. 1).

ELISA analysis confirmed these results, with findings showing an increase during midterm gestation and a decrease in infants $(p<0.01$ canalicular versus saccular and alveolar versus infants) (Fig. 2).

As far as ET-1 receptors are concerned, they were expressed on endothelial and vascular smooth muscle cells. ET-A expression was relatively strong throughout gestation $(2 \pm 0.2,1.8 \pm$ 0.4 , and $1.2 \pm 0.3$ at the canalicular, saccular, and alveolar stages, respectively, NS) (Fig. 3A). It remained stable after birth (1.66 \pm 0.6 , NS versus the fetal groups). In contrast, ET-B receptor expression was weak in the canalicular stage $(0.97 \pm 0.1)$ then increased markedly thereafter $(2.34 \pm 0.57$ and $2 \pm 0.1$ at saccular and alveolar stages, respectively; $p<$ 0.001 compared with canalicular stage) (Fig. 3B). ET-B receptor expression remained stable after birth $(2.66 \pm 0.57, p<$ 0.001 versus canalicular subgroup).

eNOS. eNOS immunolabeling was detected on the vascular endothelium of all samples. Interestingly, vascular smooth muscle cells were always eNOS negative (Fig. 4). During lung development, endothelial eNOS expression was strong in the canalicular as well as in the saccular subgroups, with a comparable intensity ( $2.06 \pm 0.26$ and $2.26 \pm 0.59$, respectively). Remarkably, it fell sharply in the alveolar group $(1.23 \pm 0.25$, $p<0.01$ versus canalicular and saccular groups). It further decreased after birth $(0.71 \pm 0.07, p<0.0001$ versus canalicular subgroup) (Fig. 5).

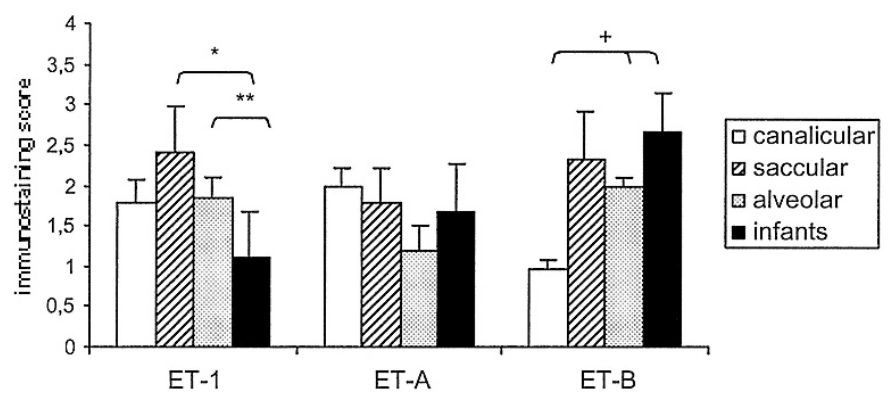

Figure 1. Histogram displaying the results of semiquantitative assessment of the expression of ET-1 and its receptors, ET-A and ET-B, using immunohistochemistry during different stages of gestation (canalicular, $n=5$; saccular, $n=5$; alveolar, $n=4)$ and in infants $(n=5)$. A significant difference was found between different group age. $* p<10^{-2}$; ${ }^{\circ} p<5 \times 10^{-3}$.

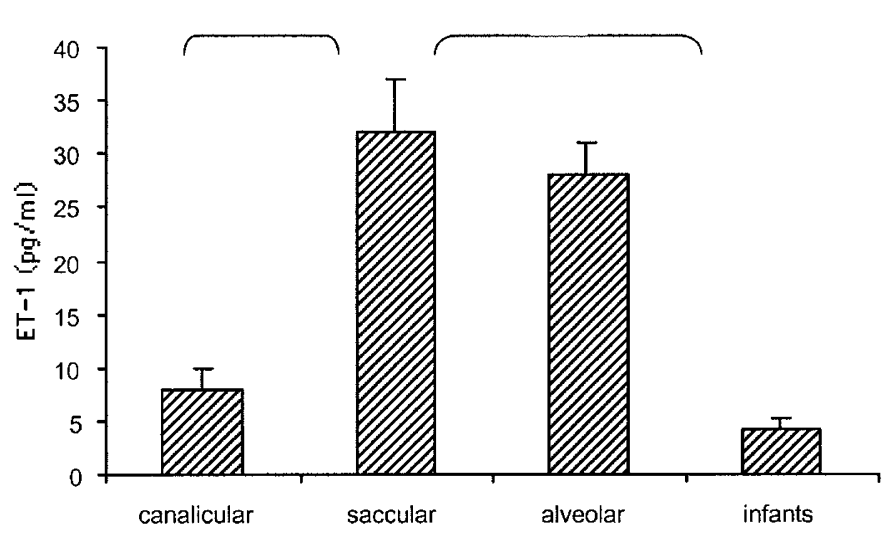

Figure 2. Histogram displaying the results of ELISA quantification of ET-1 in lung tissues during different stages of gestation (canalicular, $n=5$; saccular, $n=5$; alveolar, $n=4)$ and in infants $(n=5)$. ${ }^{*} p<10^{-2}$.

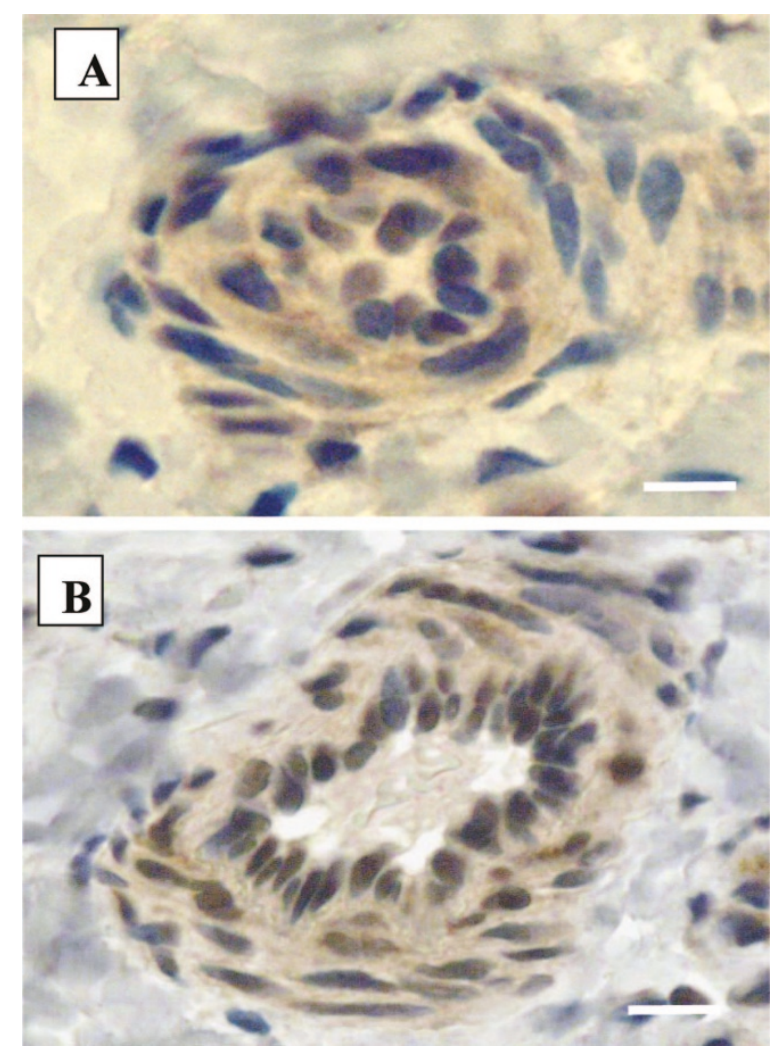

Figure 3. Immunostaining for ET-A $(A)$ and ET-B $(B)$ in lungs of fetuses at $31 \mathrm{wk}$ gestation showing endothelial and smooth muscle cell expression. Scale bar $=50 \mu \mathrm{m}$.

Western blot analysis confirmed these findings, revealing a band of $140 \mathrm{kD}$ corresponding to the eNOS protein in the lung of all subjects. In addition, densitometric analysis confirmed the quantitative immunohistochemical data, showing that the eNOS content of fetal lungs increased until mid-gestation then fell during the alveolar stage before decreasing further after birth $(338 \pm 199 \%, 403 \pm 31.5 \%$, and $278 \pm 14 \%$ of the infants values in canalicular, saccular, and alveolar stages respectively; $p<0.001$ for all fetal subgroups versus infants and saccular versus alveolar stage). 

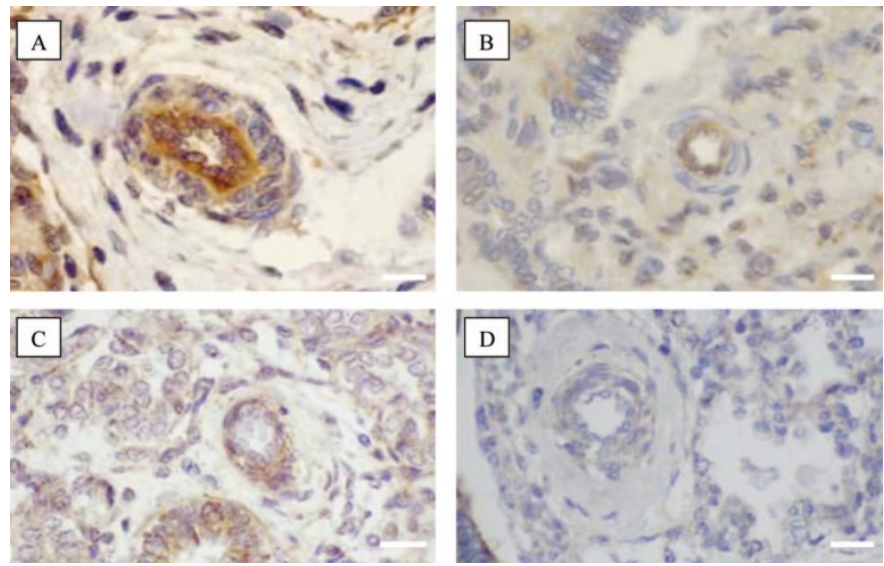

Figure 4. Immunostaining for eNOS and VEGF in lungs of fetuses and infants. (A) eNOS immunostaining at $31 \mathrm{wk}$ gestation, showing an endothelial expression of intrapulmonary artery. (B) eNOS immunostaining in an infant (aged $3 \mathrm{mo}$ ), showing an endothelial expression lower than that observed at 31 wk gestation. (C) VEGF immunostaining at 31 wk gestation. (D) VEGF immunostaining in an infant (aged $3 \mathrm{mo}$ ), lower than that observed in the fetuses. Scale bar $=100 \mu \mathrm{m}$.

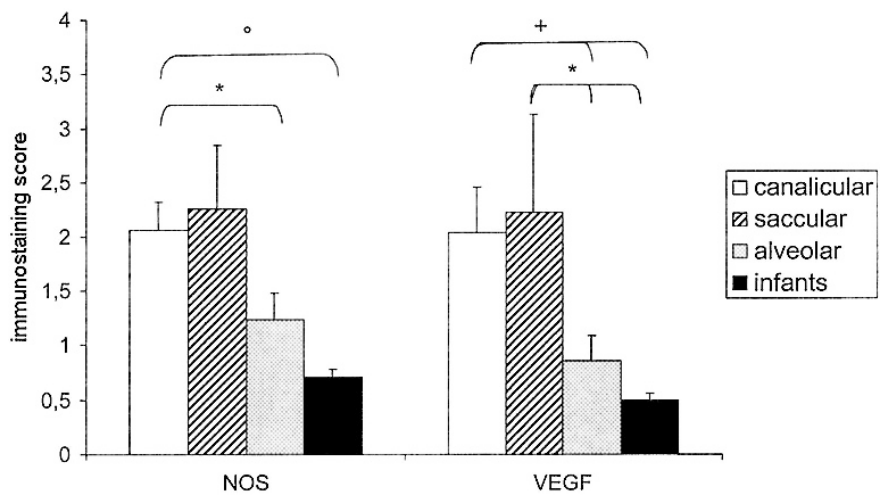

Figure 5. Histogram displaying the results of semiquantitative assessment of the expression of eNOS and VEGF using immunohistochemistry during different stages of gestation (canalicular, $n=5$; saccular, $n=5$; alveolar, $n=$ $4)$ and in infants $(n=5)$. A significant difference was found between different age groups. $* p<10^{-2}$; ** $p<10^{-4}$; ${ }^{\circ} p<5 \times 10^{-3}$.

The values are expressed as a percentage of the band obtained in the infants (Fig. 6).

$\boldsymbol{V E G F}$. Pulmonary arterial smooth muscle cells expressed VEGF throughout gestation (Fig. 4), whereas the endothelial cells expressed it only after birth. The arterial smooth muscle cell expression of VEGF was particularly intense during early gestation $(2.04 \pm 0.26$ and $2.23 \pm 0.91$ at the canalicular and saccular stages, respectively) (Fig. 5), then fell sharply during the alveolar stage $(0.86 \pm 0.22 ; p<0.001$ and $p<0.01$ versus the canalicular and saccular stages, respectively). It further decreased after birth $(0.5 \pm 0.06 ; p<0.001$ and $p<0.01$ versus the canalicular and saccular stages, respectively).

Western blot analysis confirmed these findings, showing a band of $42 \mathrm{kD}$ corresponding to VEGF protein in all lung samples. Semiquantitative densitometric analysis of Western blots showed that VEGF content was highest in mid-gestation then fell markedly, in keeping with the immunohistochemical results $(253 \pm 22 \%, 416 \pm 93 \%$, and $185 \pm 6.5 \%$ of the infants values in canalicular, saccular, and alveolar stages,

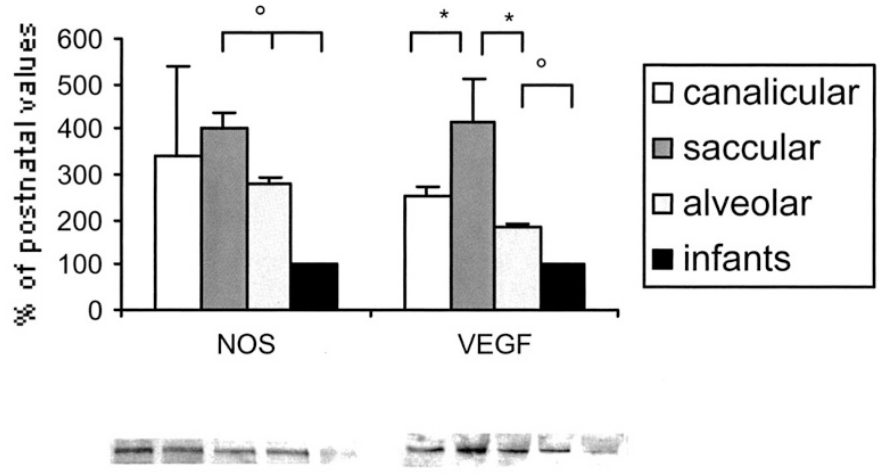

Figure 6. Western blot analysis for eNOS protein and VEGF in lung tissue from fetuses at different ages and in infants. Fifty micrograms of protein extracted from lung tissues at different ages were separated on an $8 \%$ SDSpolyacrylamide gel and analyzed using a specific antiserum raised against eNOS or VEGF. The upper panel shows the mean densitometric values expressed as a percentage of postnatal data in each developmental group (canalicular, $n=5$; saccular, $n=5$; alveolar, $n=4)$ and in infants $(n=5)$. The lower panel shows individual Western blot findings in fetuses at different ages $(24,31,33$, and $36 \mathrm{wk}$ of gestation) and in one infant. Both proteins are increased during midterm gestation and lower in infants.

respectively; $p<0.001$ for all fetal subgroups versus infants and saccular versus alveolar stage, $p<0.01$ canalicular versus saccular stage) (Fig. 6).

\section{DISCUSSION}

We examined changes in ET-1, eNOS, and VEGF protein expression during human lung development by means of immunohistochemistry and Western blotting. We found that VEGF and eNOS expression rose rapidly during gestation, peaking at $75 \%$ of term, before falling in the alveolar stage and after birth. ET-1 expression was high throughout gestation, then decreased after birth.

To our knowledge, this is the first ontogenic study of these endothelial vasoactive and angiogenic mediators in the human perinatal lung. Previous data were obtained in animal studies and exhibited some apparent discrepancies. For instance, eNOS and ET-1 expression were found to increase before birth in lambs and after birth in rats and to be similar before and after birth in the piglets $(1,11,12)$. Differences in the timing of lung development may account for the differences observed between human and animal studies $(1,20,25)$. Our findings point to a discrepancy between the maturational and functional development of vascular structures in the human lung. Indeed, vasoactive and angiogenic growth factor expression peaked some time before alveolarization. During the perinatal period, ET-1 expression remained high, and ET-B expression was stronger than ET-A. The physiologic role of ET-1 in the fetus and newborn is unclear. Some studies of fetal animals point to a principally vasodilatory action $(15,26,27)$, whereas others favor a predominantly vasoconstrictive effect $(14,16)$. We have previously reported high plasma levels and strong pulmonary expression of ET-1 in newborn piglets, with a fall to adult levels at $3 \mathrm{~d}$ of life $(7,28)$. We also found that relaxation of pulmonary artery rings was attenuated by the endothelium in newborn piglets. This difference was attenuated by blocking 
ET-A receptors, suggesting that the vasoconstrictive effect of ET-1 at birth occurs through activation of ET-A receptors (28). In lambs, selective blockade of ET-B receptors attenuates the fall in PVR at birth, suggesting a predominantly vasodilatory effect of ET-1 through ET-B receptor activation (15). In the human lung, the net effect of ET-1 might be strongly dependent on a balance between the opposing effects of ET-A and ET-B receptor activation. The strong ET-B expression that we observed in the perinatal period could point to a predominantly vasodilatory effect of ET-1, which may contribute to the postnatal fall in PVR occurring in humans.

The importance of the vasodilatory action of NO during adaptation of the pulmonary vascular bed to extrauterine life is unclear. Kawai et al. (29) reported that, in rat fetal lung, eNOS protein and mRNA levels rise during late gestation, peak within $24 \mathrm{~h}$ after birth, and then fall to adult levels. In fetal lambs, Parker et al. (1) observed that eNOS expression rose during late gestation, fell before birth, and then rose again in the newborn. Arrigoni et al. (12) found a similar eNOS expression in fetal and newborn piglets, whereas its activity increased at birth. In our study, eNOS was expressed early in gestation, but fell to a very low level in the perinatal period. Differences in the timing of fetal lung parenchymal and vascular development between humans and animals may account for these differences in eNOS expression. We are aware of the fact that protein expression does not necessarily parallel its activity. We could not perform functional studies and evaluate eNOS activity in our samples due to the too long delay between death and autopsy in our subjects to allow functional preservation of the endothelium. However, in many animal studies, the increase in eNOS expression coincided with the onset of endothelium-dependent vasodilation $(1,30)$. This discrepancy between the decrease in eNOS expression and the onset of marked vasodilation that occurs at birth could suggest that vasoactive factors other than NO, such as prostacyclin, endothelin through ET-B activation, and EDHF, could play a role, as previously suggested in animal studies during the perinatal period $(6,8,27,28,30,31)$.

By contrast, the endothelial NOS expression might have a crucial importance in alveolar and vascular development. The gradual rise in eNOS expression that we observed during pregnancy is in keeping with the development of the pulmonary vasculature. In particular, it is noteworthy that eNOS expression peaked just before the onset of alveolarization. The temporal relationship between the development of the airways and the pulmonary vasculature is clearly established in animals, with abundant growth of intraacinar capillaries matching alveolar development (32).

VEGF is one of the major inducers of vasculogenesis and angiogenesis (33-37). It is also involved in postnatal alveolarization-treatment of newborn rats with a VEGF receptor inhibitors causes pulmonary hypertension and abnormal lung structure (19). In addition to promoting angiogenesis, VEGF plays also a role in vascular tone regulation through an acute release of NO $(38,39)$. We have found that, in the fetus, VEGF was expressed by epithelial but not endothelial cells, whereas in infants it was expressed by the endothelium. This cannot be explained by a poor endothelial preservation in the fetus, inasmuch as eNOS and ET-1 were expressed in fetal endothelial cells. This argues for a paracrine role of VEGF on vascular growth, in accordance with in vitro studies $(40,41)$. The parallel expression of eNOS and VEGF, with a peak $6 \mathrm{wk}$ before birth, just before the alveolar stage, could indicate that maturation has ended by that age in the human lung.

This study has potential limitations. Functional studies determining the role of each factor during lung development would help considerably in the understanding of birth-related vasoreactivity. Such studies are, however, impossible to perform in humans because of the usual delay between human fetus or infant death and autopsy, which does not allow for sufficient endothelium preservation.

In conclusion, we show that expression of the endothelial vasoactive factors ET-1 and eNOS and the angiogenic factor VEGF increases during the development of the human fetal lung and peaks shortly before birth. This suggests that the pulmonary vasculature reaches maturity by $75 \%$ of term. Further investigations are needed to determine the respective roles of vasodilatory mediators in the perinatal adaptation of the pulmonary vasculature.

Acknowledgments. The authors thank Anne-Marie Laval for her excellent technical assistance and Dr. Olivier Sanchez for his help with the ELISA data.

\section{REFERENCES}

1. Parker TA, le Cras TD, Kinsella JP, Abman SH 2000 Developmental changes in endothelial nitric oxide synthase expression and activity in ovine fetal lung. Am J Physiol Lung Cell Mol Physiol 278:L202-L208

2. Ivy DD, le Cras TD, Parker TA, Zenge JP, Jakkula M, Markham NE, Kinsella JP, Abman SH 2000 Developmental changes in endothelin expression and activity in the ovine fetal lung. Am J Physiol Lung Cell Mol Physiol. 278:L785-L793

3. Black SM, Johengen MJ, Ma ZD, Bristow J, Soifer SJ 1997 Ventilation and oxygenation induce endothelial nitric oxide synthase gene expression in the lungs of fetal lambs. J Clin Invest 100:1448-1458

4. Cornfield DN, Chatfield BA, McQueston JA, McMurtry IF, Abman SH 1992 Effects of birth-related stimuli on L-arginine-dependent pulmonary vasodilation in ovine fetus. Am J Physiol 262:H1474-H1481

5. Heymann MA 1999 Control of the pulmonary circulation in the fetus and during the transitional period to air breathing. Eur J Obstet Gynecol Reprod Biol 84:127-132

6. Chang JK, Moore P, Fineman JR, Soifer SJ, Heymann MA 1992 K+ channel pulmonary vasodilation in fetal lambs: role of endothelium-derived nitric oxide. J Appl Physiol 73:188-194

7. Levy M, Tulloh RM, Komai H, Stuart-Smith K, Haworth SG 1995 Maturation of the contractile response and its endothelial modulation in newborn porcine intrapulmonary arteries. Pediatr Res 38:25-29

8. Cassin S 1998 Role of prostaglandins, thromboxanes, and leukotrienes in the control of the pulmonary circulation in the fetus and newborn. Semin Perinatol 11:53-63

9. Ivy DD, Kinsella JP, Abman SH 1994 Physiologic characterization of endothelin A and $\mathrm{B}$ receptor activity in the ovine fetal pulmonary circulation. J Clin Invest 93:2141-2148

10. Ziegler JW, Ivy DD, Kinsella JP, Abman SH 1995 The role of nitric oxide, endothelin, and prostaglandins in the transition of the pulmonary circulation. Clin Perinatol 22:387-403

11. Xue C, Reynolds PR, Johns RA 1996 Developmental expression of NOS isoforms in fetal rat lung: implications for transitional circulation and pulmonary angiogenesis. Am J Physiol 270:L88-L100

12. Arrigoni FI, Hislop AA, Pollock JS, Haworth SG, Mitchell JA 2002 Birth upregulates nitric oxide synthase activity in the porcine lung. Life Sci 70:1609-1620

13. Yanagisawa M, Kurihara H, Kimura S, Tomobe Y, Kobayashi M, Mitsui Y, Yazaki Y, Goto K, Masaki T 1988 A novel potent vasoconstrictor peptide produced by vascular endothelial cells. Nature 332:411-415

14. Ivy DD, Kinsella JP, Abman SH 1996 Endothelin blockade augments pulmonary vasodilation in the ovine fetus. J Appl Physiol 81:2481-2487

15. Ivy DD, Parker TA, Abman SH 2000 Prolonged endothelin B receptor blockade causes pulmonary hypertension in the ovine fetus. Am J Physiol Lung Cell Mol Physiol 279:L758-L765

16. Ivy DD, Parker TA, Ziegler JW, Galan HL, Kinsella JP, Tuder RM, Abman SH 1997 Prolonged endothelin A receptor blockade attenuates chronic pulmonary hypertension in the ovine fetus. J Clin Invest 99:1179-1186 
17. Perreault T, Baribeau J 1995 Characterization of endothelin receptors in newborn piglet lung. Am J Physiol 268:L607-L614

18. Maeda S, Suzuki S, Suzuki T, Endo M, Moriya T, Chida M, Kondo T, Sasano H 2002 Analysis of intrapulmonary vessels and epithelial-endothelial interactions in the human developing lung. Lab Invest 82:293-301

19. Le Cras TD, Markham NE, Tuder RM, Voelkel NF, Abman SH 2002 Treatment of newborn rats with a VEGF receptor inhibitor causes pulmonary hypertension and abnormal lung structure. Am J Physiol Lung Cell Mol Physiol 283:L555-L562

20. Haworth SG, Hislop AA 2003 Lung development-the effects of chronic hypoxia. Semin Neonatol 8:1-8

21. .Leung DW, Cachianes G, Kuang WJ, Goeddel DV, Ferrara N 1989 Vascular endothelial growth factor is a secreted angiogenic mitogen. Science 246:1306-1309

22. Pepper MS, Ferrara N, Orci L, Montesano R 1992 Potent synergism between vascular endothelial growth factor and basic fibroblast growth factor in the induction of angiogenesis in vitro. Biochem Biophys Res Commun 189:824-831

23. Peters KG, De Vries C, Williams LT 1993 Vascular endothelial growth factor receptor expression during embryogenesis and tissue repair suggests a role in endothelial differentiation and blood vessel growth. Proc Natl Acad Sci U S A 90:8915-8919

24. Lassus P, Turanlahti M, Heikkila P, Andersson LC, Nupponen I, Sarnesto A, Andersson S 2001 Pulmonary vascular endothelial growth factor and Flt-1 in fetuses, in acute and chronic lung disease, and in persistent pulmonary hypertension of the newborn. Am J Respir Crit Care Med 164:1981-1987

25. Burri PH 1974 The postnatal growth of the rat lung. 3. Morphology. Anat Rec 180:77-98

26. Cassin S, Kristova V, Davis T, Kadowitz P, Gause G 1991 Tone-dependent response to endothelin in the isolated perfused fetal sheep pulmonary circulation in situ. J Appl Physiol 70:1228-1234

27. Wong J, Fineman JR, Heymann MA 1994 The role of endothelin and endothelin receptor subtypes in regulation of fetal pulmonary vascular tone. Pediatr Res 35:664-670

28. Levy M, Souil E, Sabry S, Favatier F, Vaugelade P, Mercier JC, Dall'Ava-Santucci J, Dinh-Xuan AT 2000 Maturational changes of endothelial vasoactive factors and pulmonary vascular tone at birth. Eur Respir J 15:158-165

29. Kawai N, Bloch DB, Filippov G, Rabkina D, Suen HC, Losty PD, Janssens SP, Zapo WM, de la Monte S, Bloch KD 1995 Constitutive endothelial nitric oxide synthase gene expression is regulated during lung development. Am J Physiol 268:L589-L595

30. Shaul PW, Farrar MA, Magness RR 1993 Pulmonary endothelial nitric oxide production is developmentally regulated in the fetus and newborn. Am J Physio 265:H1056-H1063
31. Cornfield DN, McQueston JA, McMurtry IF, Rodman DM, Abman SH 1992 Role of ATP-sensitive potassium channels in ovine fetal pulmonary vascular tone. Am J Physiol 263:H1363-H1368

32. Jakkula M, Le Cras TD, Gebb S, Hirth KP, Tuder RM, Voelkel NF, Abman SH 2000 Inhibition of angiogenesis decreases alveolarization in the developing rat lung. Am J Physiol Lung Cell Mol Physiol 279:L600-L607

33. Shalaby F, Rossant J, Yamaguchi TP, Gertsenstein M, Wu XF, Breitman ML, Schuh AC 1995 Failure of blood-island formation and vasculogenesis in $f k-1$ deficient mice. Nature 376:62-66

34. Shalaby F, Ho J, Stanford WL, Fischer KD, Schuh AC, Schwartz L, Bernstein A, Rossant J 1997 A requirement for $F l k-1$ in primitive and definitive hematopoiesis and vasculogenesis. Cell 89:981-990

35. Fong GH, Rossant J, Gertsenstein M, Breitman ML 1995 Role of the FLT-1 receptor tyrosine kinase in regulating the assembly of vascular endothelium. Nature 376:66-70

36. Carmeliet P, Ferreira V, Breier G, Pollefeyt S, Kieckens L, Gertsenstein M, Fahrig M, Vandenhoeck A, Harpal K, Eberhardt C, Declercq C, Pawling J, Moons L, Collen D, Risau W, Nagy A 1996 Abnormal blood vessel development and lethality in embryos lacking a single VEGF allele. Nature 380:435-439

37. Ferrara N, Carver-Moore K, Chen H, Dowd M, Lu L, O'Shea KS, Powell-Braxton L, Hillan KJ, Moore MW 1996 Heterozygous embryonic lethality induced by targeted inactivation of the VEGF gene. Nature 380:439-442

38. Grover TR, Zenge JP, Parker TA, Abman SH 2002 Vascular endothelial growth factor causes pulmonary vasodilation through activation of the phosphatidylinositol3-kinase-nitric oxide pathway in the late-gestation ovine fetus. Pediatr Res 52:907912

39. Grover TR, Parker TA, Zenge JP, Markham NE, Kinsella JP, Abman SH 2003 Intrauterine hypertension decreases lung VEGF expression and VEGF inhibition causes pulmonary hypertension in the ovine fetus. Am J Physiol Lung Cell Mol Physiol 284:L508-L517

40. Brown KR, England KM, Goss KL, Snyder JM, Acarregui MJ 2001 VEGF induces airway epithelial cell proliferation in human fetal lung in vitro. Am J Physiol Lung Cell Mol Physiol 281:L1001-L1010

41. Shifren JL, Doldi N, Ferrara N, Mesiano S, Jaffe RB 1994 In the human fetus, vascular endothelial growth factor is expressed in epithelial cells and myocytes, but not vascular endothelium: implications for mode of action. J Clin Endocrinol Metab $79: 316-322$ 